(RESEARCH ARTICLE)

\title{
Spatial distribution and seasonal variation of Limicolaria spp. infesting banana plantations in South West, Cameroon
}

\author{
Okolle Nambangia Justin 1,2,*, Tientcheu Cheke Limunga Bernadette 3,4, Monono Ekwa Yawa 1,4, Ngone \\ Abwe Dione Mercy ${ }^{1}$ and Mih Afui Mathias ${ }^{4}$

\begin{abstract}
${ }^{1}$ Institute of Agricultural Research for Development (IRAD) Ekona, South West Region, Cameroon. ${ }^{2}$ African Research Centre on Bananas and Plantains (CARBAP) Njombe, Littoral Region, Cameroon.

${ }^{3}$ Cameroon Development Corporation (CDC), Tiko Banana Plantations, South West Region, Cameroon.

${ }^{4}$ Department of Botany and Plant Physiology, University of Buea, Cameroon.
\end{abstract}

Publication history: Received on 17 August 2019; revised on 21 September 2019; accepted on 23 September 2019

Article DOI: https://doi.org/10.30574/wjarr.2019.3.2.0052

\begin{abstract}
This study was carried out as a prelude to elucidate a management plan that could limit residues in fruits and the environment without compromising quality. In order to meet our objectives, snails were randomly sampled from banana growth stages, different plant parts, residues, polythene bag-covered and uncovered banana bunches, and at different distances from the field edges. To assess seasonality of snail infestations, snails were sampled from the preflowering growth stage (January to September, 2012). The egg-laying and aestivating behaviours of snails were assessed by counting them from residues, weeds and soil. We recorded a higher number of snails on growth stages and plant parts in the rainy season compared to the dry season. The number of snails were significantly higher in the preflowering growth stages in the wet season (72.1 snails/plant) compared to those from the same stage in the dry season ( 0.88 snails/plant) $(\mathrm{p}=0.05)$. Although the highest number of snails were recorded on leaves in both seasons compared to other plants parts, the numbers were significantly higher on leaves during the rainy season compared to those in the dry season $(\mathrm{p}=0.05)$. Residues were the most preferred egg-laying and aestivating sites for snails while leaves on the ground haboured the highest number of snails in both seasons. We therefore concluded that focus on monitoring and management of the snails should be intensified during the rainy season with special attention on pre-flowered plants, uncovered bunches, and residues.
\end{abstract}

Keywords: Snail; Pest; Ecology; Molluscs; Seasonal fluctuations

\section{Introduction}

Banana is one of the world's most important crops grown by small and large scale producer's alike [1]. The banana fruit is classified as a berry, a product of pathenocarpy [2] and are known to be highly nutritive and easily digestible, free from fat and cholesterol than many other fruits [3]. They constitute an excellent source of carbohydrate, vitamins, and proteins as well as good source of minerals [4, 5]. It was reported that in 2013, more than 145 million metric tons of bananas and plantains were produced in over 130 countries on more than 11 million hectares of land [6]. According to FAO [7] the annual production of banana was estimated at about 95 million tons and both bananas and plantains served as staple foods for at least 4000 million people in the world especially in sub-Saharan countries.

Banana is an important source of revenue for Cameroon with production of about 249,610 tons exported in 2016 and 279,493 tons in 2015, putting the country in second place behind Cote D'Ivoire in Africa [8]. The production of banana in Cameroon has been increasing steadily from 2001 (631,766 tons) to 2016 (1,187,547 tons), occupying the 15th position in the world with $1.5 \%$ share [9]. In Central and West Africa, bananas and plantains play an important role in

\footnotetext{
${ }^{*}$ Corresponding author

E-mail address: okollejustin@yahoo.com
} 
food security, employment, revenue, diversification and poverty reduction [10 - 13]. In Cameroon, banana plantations are mostly in the Littoral and South West Regions and these agro-industrial farms are usually faced with major biotic stresses such as Cosmopolites sordidus, burrowing nematodes, black sigatoka, mealy bugs, aphids and recently, white flies and snails [13, 14]. Limicolaria spp (snail) belongs to the Family Achatinidae [15]. This species has been reported to damage palm fruits and leguminous cover crops in Cameroon such that it was suggested to may have been a greater pest than A. fulicaor and A. marginata [16].

Although there is inadequate information on mollusca as crop pests, the status of these terrestrial gastropods, have increased greatly in the past decade [17- 21]. These pests cause damage to banana fruits by eating the peelings and this seriously affects the physical appearances of the fruits, making them not fit for exportation (Figure 1). These translate into huge losses for the banana plantations as many fruits are rejected. This explain why Cameroon Development Corporation (CDC) banana plantations have been losing yield due to snails damages especially on banana bunches in Holforth (Tiko) and Ekona.. Holforth (Tiko) showed an increase in damaged bunches with time (years) while Ekona showed the reverse trend (Figure 2). In addition, these snails feed on leaves of very young plants (suckers) creating feeding holes on them.

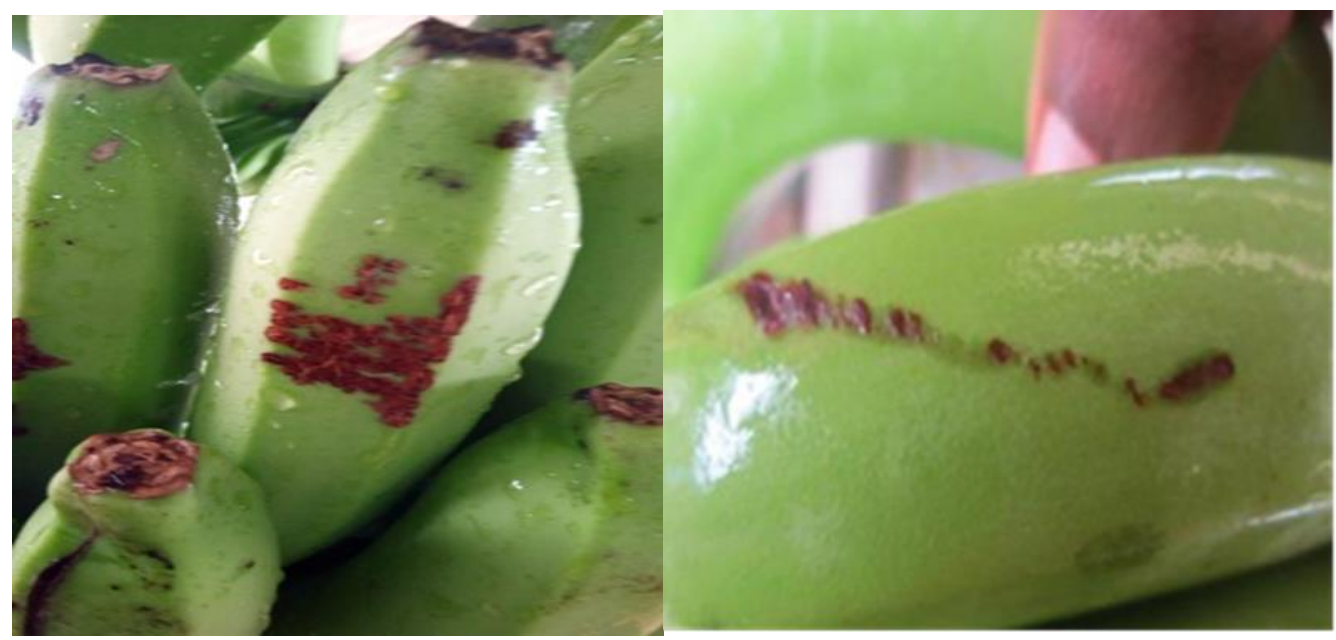

Figure 1 Fruits damaged by snails in the packing station

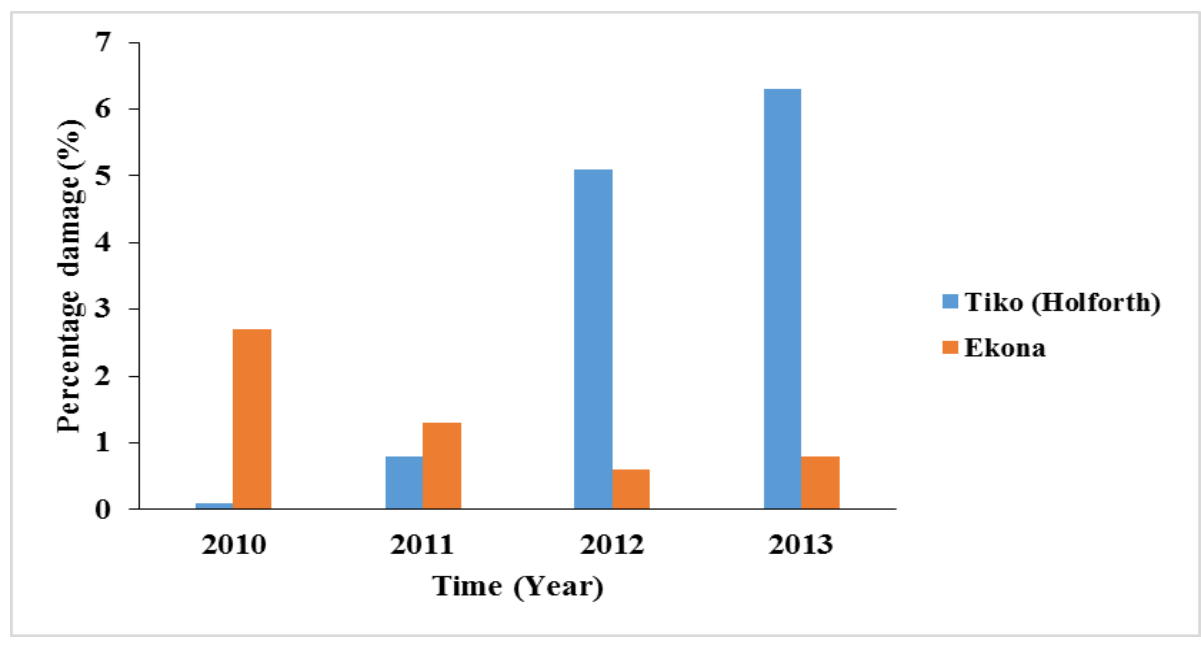

Figure 2 Percentage of banana bunches rejected as a result of snail damage for four (4) years

Since the emergence of this problem, the main management technique has been the use of molluscicides to attract and kill or the use of baits to attract and physically pick the snails. In spite of all these, the problem still persists, begging for a study of the bioecological aspects of the pest which has never been done scientifically in Cameroon and even rare worldwide. Such studies would help to reveal critical weak links in the life of this pest, which in turn will result to the formulation of effective management techniques. The specific objectives were to: (i) study the distribution of the snails in relation to banana growth stages, different parts, residues, bunches covered/uncovered with polythene bags, and 
distance from field edges (perimeter versus interiors), (ii) study the seasonal variations of snail infesting bananas and their damage on bunches, (iii) study the egg-laying and aestivating behaviour of the snails within the plantation.

\section{Material and methods}

\subsection{Study area}

This ecological study of Limicolaria species infesting bananas was carried out in the Cameroon Development Corporation (CDC) Ekona banana plantation. CDC is the second largest employer after the government and principally cultivates rubber, oil palm and banana [22]. Most CDC's operational plantations are mainly found in the South West and Littoral Regions of Cameroon. For the banana plantation, they are mostly found in Fako Division of the South West Region. The sites of this crop are therefore influenced by the local climatic conditions and soil type [22]. Ekona banana plantation is situated on the lower eastern slopes of Mount Cameroon at an altitude of $650 \mathrm{~m}$ above sea level, between $4^{\circ} 09^{\prime}-4^{\circ} 12^{\prime}$ North and longitude $9^{\circ} 17^{\prime}-9^{\circ} 20^{\prime}$ East.

The soils are rich in organic matter and nutrients which are good for banana production. The terrain is stony in nature, gently sloping, with some well drained parts of the field. The area has a dry season of five months (November - March) with very little rain and a long rainy season with excessive rainfall of $300-350 \mathrm{~mm} / \mathrm{month}$ during the peak period (June to October), no hurricanes or cyclones but a few heavy rainstorms with strong wind during the months of March and October. It has a humidity range of 75 to $80 \%$ and minimum and maximum temperature ranges of 18 to $20{ }^{\circ} \mathrm{C}$ and 30 to $35^{\circ} \mathrm{C}$ respectively.

\subsection{Distribution on different banana growth stages and parts}

According to Okolle et al. [23], growth stages in the banana plantation were categorized as peeper suckers (PSK), water suckers (WSK), pre-flowering plant (PRP), flowering plants (FP), and bunched plants (BP). The different plant parts that were considered were corms, pseudostems, leaves, and bunches. Five parcels in the plantation, with each consisting of 38 to 40 Hectares (Ha) and made up of plots which range from 1 to $8 \mathrm{Ha}$ were selected. A plot was therefore chosen per parcel based on the plantation site history and records in the past years on snail infestation. The plots chosen were those with history of high snail infestation. A total of 50 plants per plot were sampled in a random systematic pattern (that is in every 3rd row and from each row sampling done at every 5th mat) for each growth stage. For each plant and for every growth stage, the number of snails present was counted and recorded. This procedure was carried out in the dry (February) and rainy (October) season. To sample from plants that were very tall, a ladder was used to climb.

\subsection{Distribution on residues}

Different residues such as leaves on the ground (LOG), harvested pseudostems on the ground (HSG), Desuckers (DSK), bunches on the ground (BOG) and Dead mat (DM) were considered. Based on record keeping, plots with history of high level of snail infestation were chosen per parcel. From each plot, 50 residues for each category (i.e. LOG, HSG, DSK, BOG and DM) were randomly sampled. Residues were then carefully inspected and snails present counted. For each residue, the number of aestivating/non aestivating snails were noted. The different residues were also searched for eggs by digging out soil below residues and inspecting. Sampling was done from late dry and late rainy season i.e. February and October respectively.

\subsection{Infestation on bunches covered with/without perforated plastic bags}

This study was carried out in a highly infested plot chosen from each parcel, giving a total of 5 plots. From each plot, in a random systematic pattern (that is in every $3^{\text {rd }}$ row and from each row sampling done at every $5^{\text {th }}$ mat), 50 plant with bunches covered with plastic bags were chosen. This procedure was also repeated for 50 plants with bunches not covered giving a total of 100 plants per plot. For both categories (that is 50 plants with bunches covered and 50 plants with bunches uncovered) the number of snails present on the fruits were counted and fruits were also observed to record type of damage caused. Sampling was carried out within the period of February and October that is, in the dry and rainy season. A ladder was used to climb and inspect taller plants $(>1.5 \mathrm{~m})$.

\subsection{Infestation in relation to distance from field edges}

From each parcel a plot with records of high level snail's infestation were chosen. Plots chosen had borders with bushy areas or farmlands. From the edges (perimeter - considered as 0 meters) of each plot, $10 \mathrm{~m}, 50 \mathrm{~m}$, and $100 \mathrm{~m}$ points were marked into the interior of the plots using a measuring tape and for each of the marked distances, 50 plants from the most infested growth stage (pre-flowering plants) were selected, and snails on them counted as described by Okolle 
et al. [23]. This was carried out in the period of the dry season that is February to March) and late rainy season in September to October.

\subsection{Seasonal fluctuation of snail density and damage}

For seasonal changes in snail densities, five highly infested plots were chosen from the parcels and the most infested plant stage (the pre-flowering) considered for sampling. From each plot 100 plants from the most infested plant stage were sampled. This was done in a random systematic pattern ( $3^{\text {rd }}$ row and from every $3^{\text {rd }}$ row at the $5^{\text {th }}$ mat). The plant was carefully observed and number of snails counted, weekly from January 2014 to September 2014. Counting was focused on corms, pseudostems, leaves and fruits.

For seasonal damaged bunches, data were obtained from the plantations records in the packing station. Generally all bunches entering the packing stations were carefully checked to note those with different infestation resulting from pests such as mealy bugs, snails and birds. All these were gotten from rejection note books in the packing station. These records were noted weekly and monthly pooled data from January to September 2014 were used for this research. The number of damage bunches were converted to percentages.

\subsection{Egg laying and aestivating behaviour of snails within the plantation}

For egg-laying behaviour, eggs were searched from the soil, residues (leaves on the ground, harvested pseudostems on the ground, desuckers and bunches on the ground and dead mats) and within weeds in highly infested section in a parcel. Four equal number of points were chosen around selected plants and soil dug from these points. The number of eggs found was counted and recorded. Weeds and residues around selected plants were also sampled and eggs found in each pit counted. In addition, characteristics of the eggs were observed and noted. Such characteristics included shape, colour and size. For aestivating behaviour, the study was carried out in highly infested sections in each of the 5 parcels. Equal number of points (as for egg laying behaviour) for soil around plants, residues and within weeds were selected and number of aestivating snails (those whose openings were covered with a solid substance) counted and recorded. For both aestivating and egg laying behaviours, sampling was carried out during the dry season (February and March).

\subsection{Statistical analysis}

Data collected was analyzed using descriptive statistics and subjected to analysis of variance (ANOVA). The Z-test was used to compare means with two large samples. All analyses were carried out using StatDisk Software [24]. Pertinent means from the ANOVA were separated by the use of Tukey's test [25] at statistical significance set at $p \leq 0.05$.

\section{Results}

\subsection{Distribution in relation to banana growth stages and different parts}

The data provided enough evidence to show that the highest numbers of snails were recorded in the rainy season (Figure $3 \mathrm{~B}$ ) than in the dry season (Figure 3A).
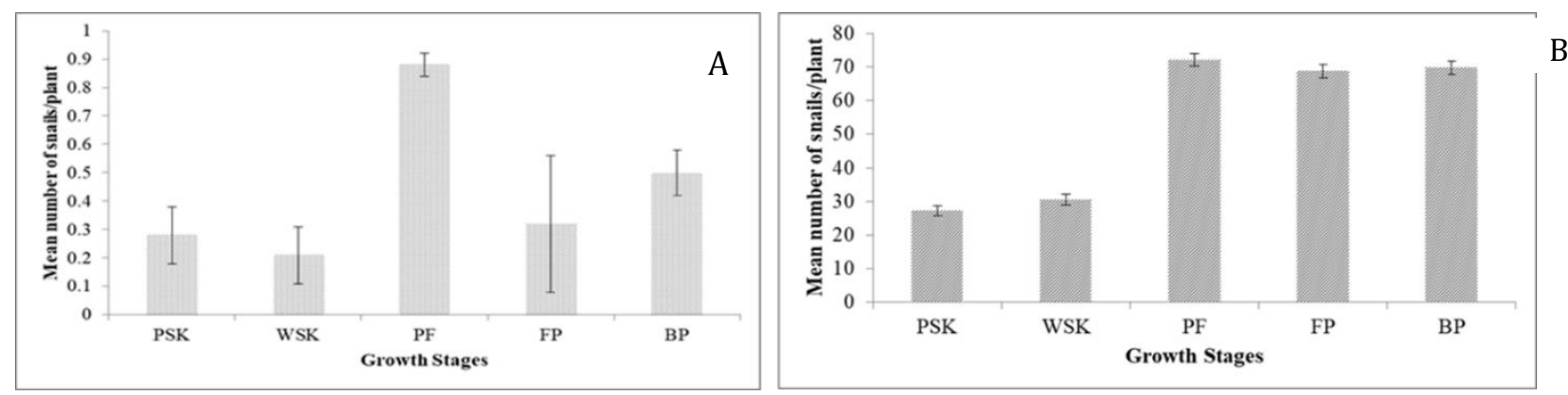

Figure 3 Mean number of snails with respect to banana growth stages in the dry (A) and rainy (B) seasons. (Peeper suckers $=\mathrm{PSK}$, water suckers $=\mathrm{WSK}$, pre-flowering plant $=\mathrm{PF}$, flowering plants $=\mathrm{FP}$, and Bunched plants $=\mathrm{BP})$.

The sample means were statistically significantly higher in the rainy season as compared to the dry season ( $\mathrm{p}<0.0001$ ). It was also observed that pre-flowering plant had the highest mean number of snail infestation per plant for the dry and rainy seasons ( 0.88 and 72.1 snails/plant respectively). 
In Figure 4A, during the dry season, number of snails on different plant parts was highest on the leaves (0.6 snails/plant) followed by pseudostem ( 0.5 snails/plant), corm ( 0.4 snails/plant) and bunches had the lowest ( 0.2 snails/plant). Snails were found more on the upper surfaces of the leaves and this was statistically significant $(\mathrm{p}=0.042)$. No statistical difference was obtained between the mean number of snails on corms and pseudostems within the dry season. On the other hand, the mean number of snails between these parts in the rainy season was marginally different, with pseudostems recording the highest number. However, a statistically higher mean number of snails was recorded on the leaves (32.5 snails) compared to the corms (10.3 snails) and pseudostems (23.2 snails) in the rainy season (Figure 4B) $(\mathrm{p}<0.05)$.
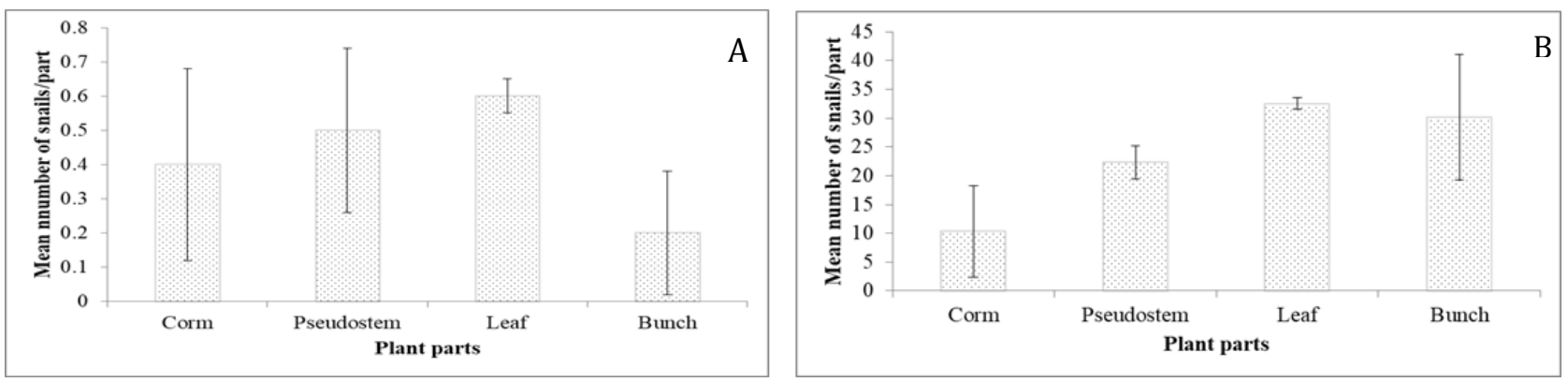

Figure 4 Mean number of snails with respect to different banana plant parts in the dry season (A) and in the rainy season (B).

\subsection{Distribution in relation to different residues}

Results for the mean number of snails for the different residues are shown in Figure 5. When data for both the dry season (Figure 5A) and rainy season (Figure 5B) were compared, the mean number of snails in residues for the rainy season (2.2 snails), was statistically significantly higher than the number of snails recorded in the dry season (0.79 snails). Leaves on the ground recorded significantly higher number of snails for the dry and rainy seasons with 0.42 snail/plant $(\mathrm{P}<0.0001)$ and 1.30 snail/plant $(\mathrm{P}=0.02)$ respectively as compared with the other residues. No snail was found on desuckers in both seasons (Figures 5 A \& B).
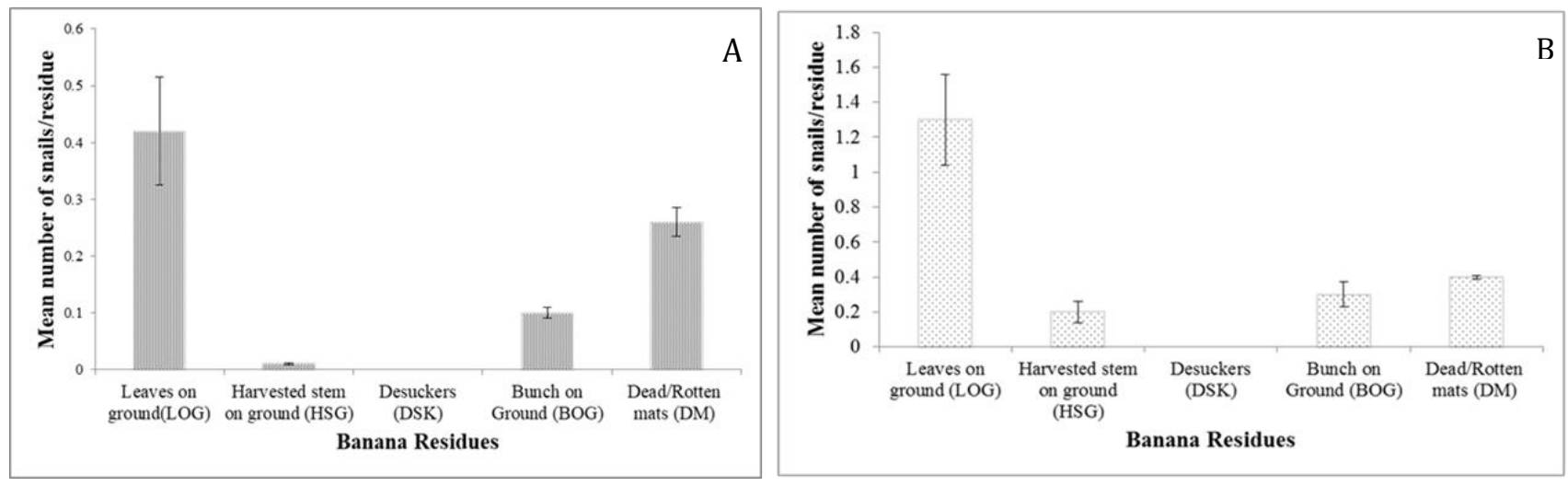

Figure 5 Mean number of snails within residues in the dry season (A) and rainy season (B).

\subsection{Infestation on bagged and unbagged bunches}

In the dry season there was no significant difference in the mean number of snails on covered and uncovered bunches (Figure $6 \mathrm{~A}$ ). However, those without polythene plastics bags had the highest level of snail infestation $(0.02$ snails/bunch) relative to those with polythene plastic bags (0.003 snails/bunch). For the rainy season, highest number of snails were recorded on bunches not covered with plastic bags (29.3 snails/bunch) compared with the uncovered bunches (6.7 snails/bunch) as shown in Figure 6B. The means were statistically $(\mathrm{p}<0.05)$. 

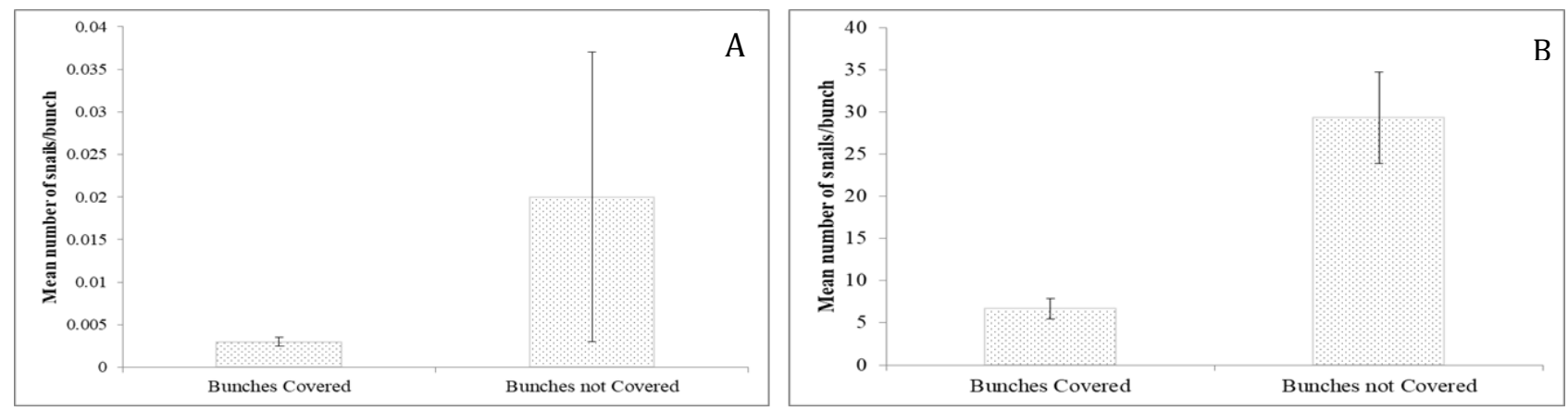

Figure 6 Mean number of snails in bunches covered with plastic and bunches not covered with plastics in dry season (A) and rainy season (B).

\subsection{Distribution in relation to distance from field edges}

Data collected for field edge snail counts are on Figure 7A and B. Analyses revealed that the mean number of snails in the dry season was significantly lower compared with mean numbers collected at distances in the rainy season $(p<0.05)$. In both seasons the number of snails at the different distances showed a decrease in the number of snails from $0 \mathrm{~m}$ to $100 \mathrm{~m}$ into the plantation (Figure $7 \mathrm{~A}$ and $\mathrm{B}$ ).
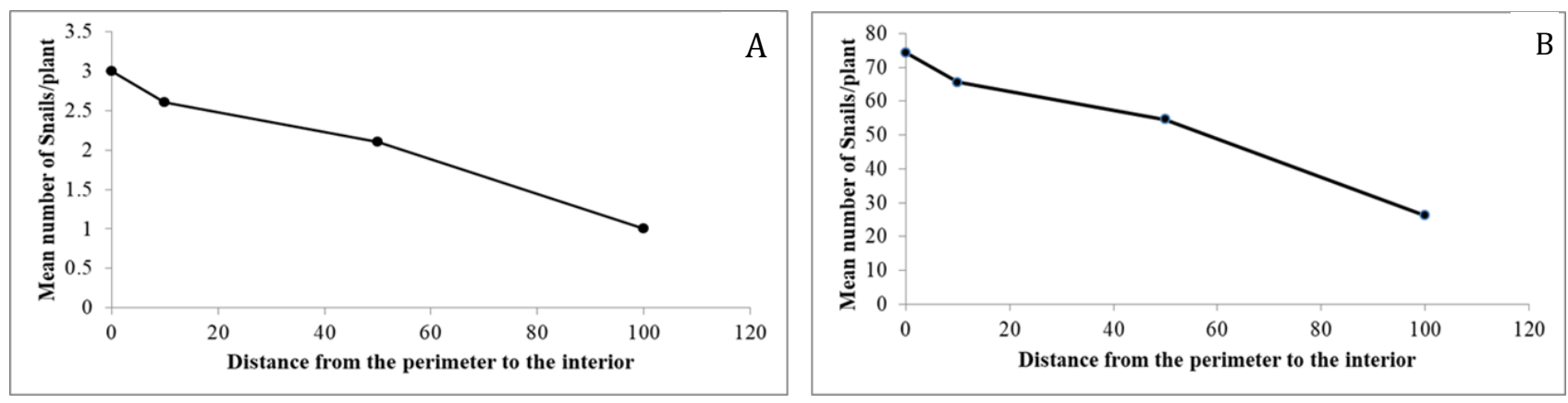

Figure 7 Mean number of snails at perimeters and interior of the plantation in dry season (A) and rainy season (B)

\subsection{Seasonal variation and infestation of the snails}

It was observed that the total number of snails on banana plants were highest in August and September while the lowest total population was from January to April (Figure 8). Records of damaged bunches in the packing station also showed an increase in number in the rainy compared to the dry season (Figure 8). There was also a positive correlation between snail densities and bunches damaged from the packing station (Figure 9).

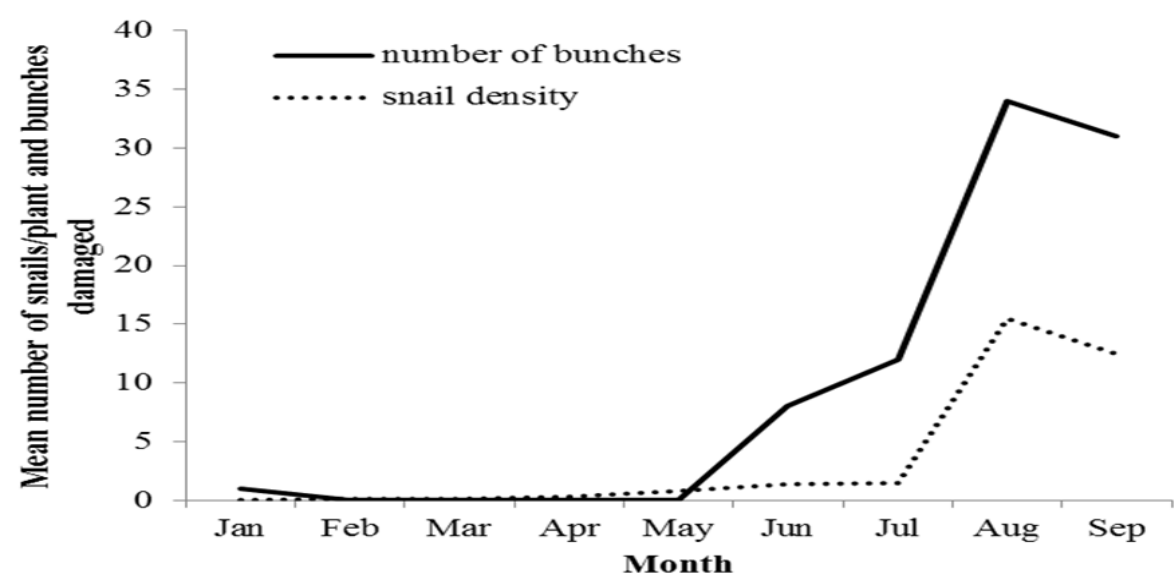

Figure 8 Seasonal variation of snail mean density in Ekona banana plantation and mean number of bunches rejected at the pack house 


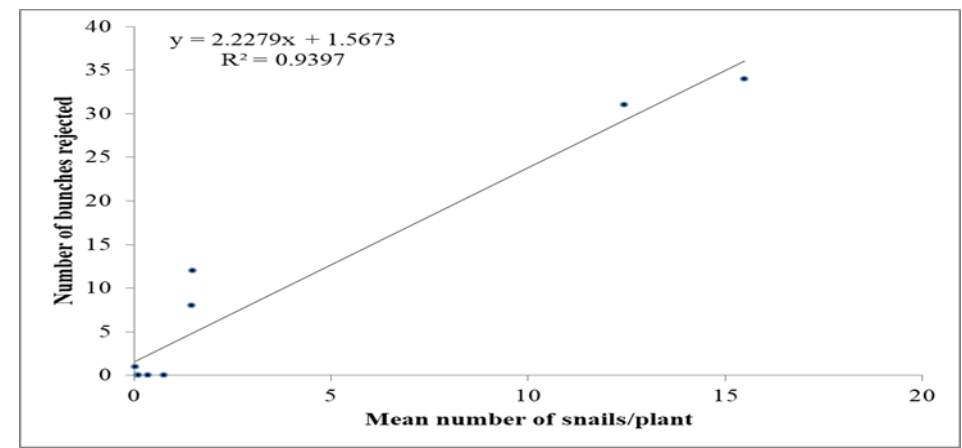

Figure 9 Correlation of mean density of snails in plant and bunches rejected in 2012

\subsection{Egg laying and aestivation sites within the plantation}

The mean number of snail eggs found from the different residues were not significantly different $(p=0.905)$. However residues recorded the highest mean number of eggs ( 0.12 eggs) as compared to weeds ( 0.10 eggs) and soil ( 0.09 eggs) (Figure 10). For aestivating behaviour, data showed that there was a statistically significant difference in the mean number of snails sampled in different sites $(\mathrm{p}<0.0001)$. As residues recorded the highest mean number of aestivating snails ( 0.67 snails) and compared with soil ( 0.05 snails) and weeds ( 0.10 snails) (Figure 11$)$.

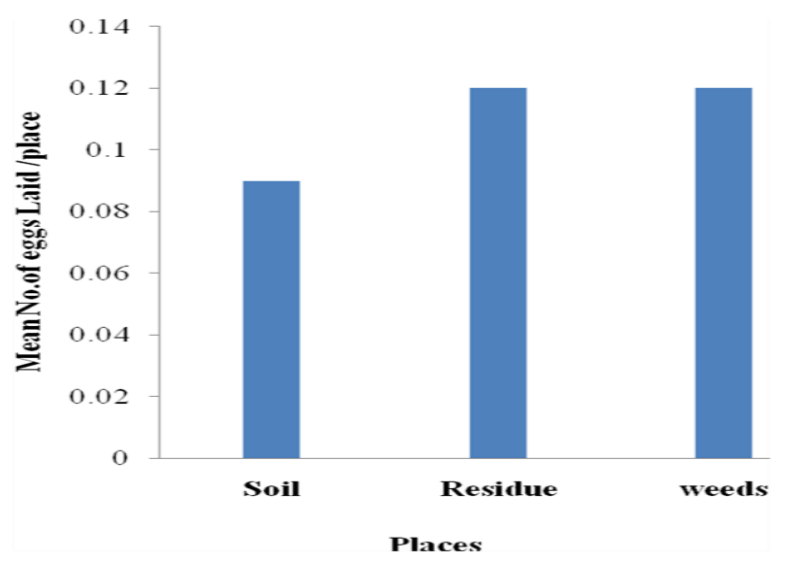

Figure 10 Mean number of eggs laid per site

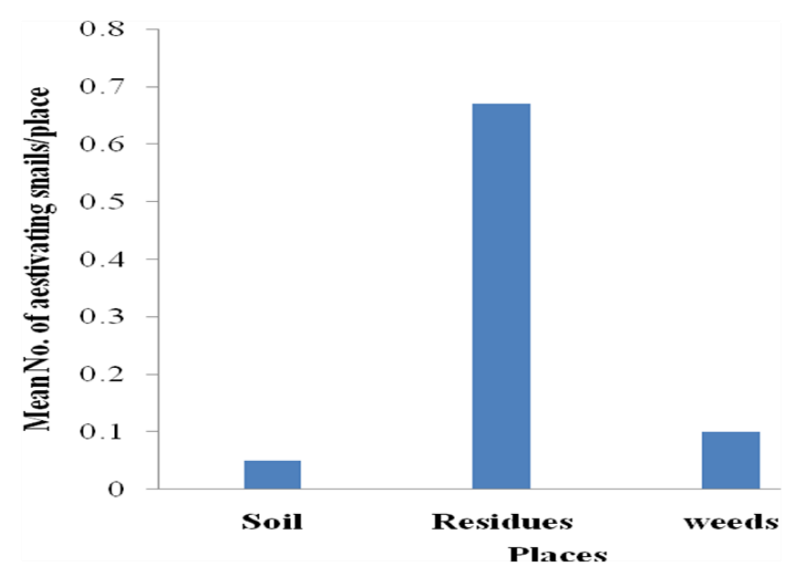

Figure 11 Mean number of snails aestivating by sites 


\section{Discussion}

The distribution of snails in relation to banana growth stages showed that the highest significant mean number of snails was recorded on the pre-flowering (PF) growth stage compared with the other growth stages. This may be due to the fact that this stage has many and broader leaves which may act as shades from sunlight especially when the leaves are opposite one another. Our finding corroborates those of Ahmed and El- Wakeil [21] who reported that snails preferred habitats offering shelter and adequate moisture.

The highest mean number of snails was recorded on leaves compared with the other parts in both the rainy and dry seasons. The pseudostem and corm recorded the lowest mean number of snails in the rainy compared with the dry season. This may be as a result of a lot of moisture on the ground causing the snails to climb right to the top. This agreed with the findings of Cobbinah et al. [26] that snails needed damp but not very wet environments for survival. Although snails need moisture for survival, they may drown in overly wet surroundings. Knowledge of snail distribution with respect to growth stages and parts will enable a better crop management technique for snail control.

In residues, snails showed significantly higher differences in mean numbers on leaves on the ground in both rainy and dry seasons compared with other residues. This could be attributed to the fact that most of the leaves were decayed and the place was damp and cool and therefore preferred by the snails as previously reported [27, 15]. The lack of snails in desuckers could be as a result of the fact that the plants were not decayed and the place was not damp and cool. It may also be the result of snails having fallen off during pruning. The implementation of snail management activities here can be used to develop a prescription that will better manage the snail pest.

Uncovered banana bunches had highest mean number of snail infestation than bunches covered with plastic in the rainy and dry season. It was shown that snails preferred infesting immature fruits to mature fruits. This may be because the immature fruits tissue is softer than the mature fruits. This was reported by Ahmed and El- Wakeil [21] who said that snails eat leaves, roots and tubers of nearly all vegetable fields, garden and greenhouse. This knowledge will lead to the optimal use of plastic bags for snail management and also enable fruits to be bagged timely to prevent snail infestation.

The highest mean number of snail was recorded for boarder plants $(0 \mathrm{~m})$ for both seasons as compared to the other distances in relation to distance from field edges. This could be as a result of the bushes and farmland around the area and also due to the fact that there are a lot of agrochemical applications done in the interior than at the border. The areas closest to the bushes, farm lands and water or streams had a lot of snails. This work is in line with the work of Ahmed and El- Wakeil [21] who observed that snails tended to prefer habitats with abundant food supply. Raut and Barker [28] also reported Limicolaria spp. thrive in modified forests, and at forest edges. Our current finding could lead to management of the pest done on prescription basis thereby making it more efficient. Barriers or traps could be put in these areas to prevent snails from getting into the plantation.

Assessing seasonality and season related damages of bunches, we observed that the mean number of snail infestation was recorded highest in the rainy season with August recording the highest mean number (15.5) of snails infestation as compared to the other months. This month also recorded highest for bunches damage by snails in the packing station. This could be as a result of the rains. During the dry season snails go into hiding because the condition are not favourable for their survival and comes out when there is enough moisture for their survival. Ahmed and El- Wakeil [21] reported a similar observation following rains where terrestrial snails came out of hiding during the day. On the other hand Long [27] reported that moisture was key to snail survival. Raut and Barker [28] said that Limicolaria spp. survive in cold, mountainous climates and may be regarded as temperate. That is why they are commonly observed at beginning, during, and/or just after the rainy season. We can explain that snail remains very active in increasing rainfall, as temperature decreases with time. This was also supported by Floyd et al. [15] who mention that snails are active at low temperature. An application of this knowledge will tend to reduce production cost. Management will be limited to prescribed months and not all the months. Snails feed on the fruit peel by chewing thereby causing brown necrotic spots on the fruits as seen in Plate 4.1. The damage caused by these pests lead to serious financial loss in export because the fruits or parts of the fruits were not marketable. At the Holforth plantation in Tiko, the percentage increased in bunches damaged during the three years compared with Ekona. This could be as a result of the fact that the management strategies such as handpicking used in Ekona was effective to that of Holforth (Tiko) this knowledge would enable the management to intensify supervision in the control strategies used in controlling pests.

Snail eggs are small in size, round and pale yellow in colour. Eggs were seen in residues with a range from 1 to 25 eggs in number. The mean number of snail eggs from the different areas was not significantly different. However, eggs were higher in residues as compared to weeds and soils, similar to the observations of Long [27] who reported a higher number of egg ranges laid in masses of up to 100 eggs in diverse location such as soils, debris, rocks and plants. Snails 
aestivating also showed significantly high mean numbers in residues (0.67) compared with soils and within weeds. Snails were noticed to aestivate during the dry season, falling in line with the report of Cobbinah et al. [26] who observed that high temperatures and low humidity were not very good for snail survival. Snails also tended to aestivate when temperatures were not favourable for their survival. When temperatures are high, the snail retracts its entire body inside the shell, sealing off the opening with a white calcareous layer [26]. They aestivate to prevent water lost from the body. The effective application of these pests control strategies would reduce cost and therefore be cost effective for the management.

\section{Conclusion}

This study showed that seasonal variation and distribution pattern of Limicolaria spp. greatly influence the infestation of banana in the plantations. A better management technique or plan can be projected for the snails as it was abundant in the rainy season with significant population of the snails on the pre-flowering leaves of banana and residues especially at the perimeters of the plantations.

\section{Compliance with ethical standards}

\section{Acknowledgments}

The management of Cameroon Development Corporation (CDC) Banana for permission to allow the second author to carry out this M.Sc. research in their plantations. Agro Vital Services and Consulting (AGROVISC) Buea, Cameroon for help in statistical analysis.

\section{Disclosure of conflict of interest}

Authors have declared that no competing interests exist.

\section{References}

[1] Edward EB. (2012). Banana Market. IPAS Extension, 1-10.

[2] Daniells J, Jenny C, Karamura D and Tomekpe K. (2001). Musalogue: A catalogue of Musa germplasm. Diversity in the genus Musa (Amaud, E., and Starnek, S., compile). International Network for Improvement of Banana and Plantain Montpellier, France, 1-5.

[3] Debabandya M, Sabyasachi M and Nanrata S. (2010). Banana and its by-products utilization: an overview. Journal of Scientific and Industrial Research, 69, 323-329.

[4] Rasheed A. (2003). Plantain production as a business. HORT-Magazine, 1 (1), 11-12.

[5] Ajoy K, Bhabatosh H, Nishith R and Sourav B. (2011). An overview on different variety of Musa species: importance and its enormous pharmecological action. IYPI's. Journal of Pharmacognosy and Herbal Formulations, 2, 1-11.

[6] FAO. (2015). FAOSTAT banana production. Available at http:/faostat 3.fao.org/home/index.html. Last assessed on $15 / 09 / 2016$

[7] FAO 2010. Recent developments in global banana market. http://www.fao.org/ DOWNLOAD Last assessed on 07/09/2019

[8] Mbodiam BR. (2018). Cameroon Banana Export Report. Business in Cameroon Online Magazine.

[9] FAO (2016). Bananas facts and figures. http://www.fao.org/ economic/est/est-commodities/bananas/ bananafacts/en/ Last assessed on 07/09/2019

[10] Temple L, Chataigner J and Kamajou F. (1996). Le marche du plantain au Cameroun, des dynamiques de l'offre au fonctionnement du système de commercialisation. Fruits, 51(2), 83-98.

[11] Noupadja P. (2000). De Nouvelle Variete de Bananiers Plantains resistantes à la maladie des raies naives sont disponible au CRBP. Plantainfo, 41, 7.

[12] Jacobsen K, Fogain R, Mouassom H and De Waale D. (2004). Musa-based cropping systems of the Cameroon high lands. A case study of the West and North West Provinces of Cameroon with emphasis on Nematodes fruits. 59(5), 311-312. 
[13] Okolle JN, Fansi G, Lombi F, Lang P and Roubana P. (2009). Banana entomological research in Cameroon: How far and what next? The African Journal of Plant Science and Biotechnology, 3(1), 1-19.

[14] Okolle JN, Nkwenti Marie-Claire Lum, Christopher Ngosong, Lawrence Tatanah Nanganoa, Tanyi Clovis, Nekongo Peter Sakwe and Afuh Mathias Mih. (2018). Efficacy of four plant emulsions for managing long tail mealybugs (Pseudococcuslongispinus) infesting banana plantations in Cameroon. Journal of Entomology and Zoology Studies, 6(3), 837-843.

[15] Floyd J, Roda A, and Robinson DG. (2007). New Pest Response Guidelines Giant African Snails: snail pests in the family Achatinidae. USDA-APHIS-PPQ-Emergency and Domestic Programs-Emergency Planning, Riverdale, Maryland, 3- 13.

[16] Mead AR and Palcy L. (1992). Two giant African land snail species spread to Martinique, French West Indies. The Veliger, 35(1), 74-77.

[17] Barker M. (2003). Molluscs as crop pests. Crop Protection, 22, 1063-1064.

[18] Ebenso IE, Ita B, Umoren EP, Ita M, Binang W, Edet G, Izah M, Udo IO, Ibanga G and Ukpong, EE. (2005). Effect of Carbamate Molluscicide on African Giant Land Snail Limicolaria Aurora. Journal of Applied Sciences \& Environmental Management, 9 (1), 99-102.

[19] Fongod A, Focho D, Mih A, Fonge B and Samalang P. (2010). Weed management in banana production. The use of Nelsoniacanescens (LAM) spreng as a non-leguminous cover crop. African Journal of Environmental Science and Technology, 4(3), 167-173.

[20] Nazeer M. (2011). Snail a new pest. Kannur Bracing for Battle against G Hendersont African Snails. 7 - 9.

[21] Ahmed S and El-Wakeil N. (2012). Biological and ecological studies on land snails and their control, integrated pest management and pest control, 413-444.

[22] Jude N and Nkwanguh G. (2013). A Comparative Assessment of the effects of climatic variations on the crops of Cameroon Development Corporation (CDC). Adaptation Options Environment and Natural Resources Research, 3(1), 144-156.

[23] Okolle JN, Mashhor M and Abu Hassan A. (2006). Spatial distribution of banana skipper (Erionota thrax L.) (Lepidoptera: Hesperiidae) and its parasitoids in a Cavendish banana plantation, Penang, Malaysia. Insect Science, 13, 237-241.

[24] Mario F, Gilmartin W, Solberg E and Abueisaad T. (2003). Statdisk 9.1 for Elementary Statistics (9thEdn), Pearson Education.

[25] Fowler J, Cohen L and Javis P. (1998).Practical Statistics for Field Biology (2nd End), John wiley and sons, Chichester, UK, 257 - 258.

[26] Cobbinah J, Adri V and Ben 0. (2008). Snail farming, production, processing, and marketing. Agrodok, 47, 78.

[27] Long B. (1996). Coping with Slug and Snails. Journal of Pesticides Reform, 16 (1), 22-33.

[28] Raut SK and Barker GM. (2002). Achatina fulica Bowdich and other Achatinidae as pests in Tropical Agriculture. In: Molluscs as CropPests, CAB International, 3, 55-114.

\section{How to cite this article}

Okolle NJ, Tientcheu Cheke LB, Monono EY, Ngone AM and Mih AM. (2019). Spatial distribution and seasonal variation of Limicolaria spp. infesting banana plantations in South West, Cameroon. World Journal of Advanced Research and Reviews, 3(2), 36-45. 